\title{
Studi Meaning of Life Siswa SMP di Pondok Pesantren An-Nur II Al Murtadlo Bululawang Kabupaten Malang
}

\author{
Feny Andriyanti, Nur Hidayah, IM Hambali \\ Jurusan Bimbingan dan Konseling, Fakultas Ilmu Pendidikan, Universitas Negeri Malang, \\ e-mail: feny.andriyanti95@gmail.com
}

\begin{abstract}
Pondok pesantren is one of typical Indonesian Islamic educations, which have a philosophy as a way of life (meaning of life). The meaning of life will underlie the behavior of students in performing daily activities in order to achieve happiness. The aim of this research is to know the meaning of life achievement of the Junior High School students in pondok pesantren An-Nur II Al Murtadlo. This research used descriptive quantitative research design with survey method. The results of research showed that the Junior High School students in pondok pesantren An Nur II Al-Murtadlo have a high meaning of life with $63 \%$ percentage. However, there are three sources of value that have different achievement, the highest achievement is the values of experiential of love and religion, which is $37 \%$, the values of attitudinal of striving, which is $34 \%$, and the values of work creativity which is $29 \%$. It can be interpreted that the experiential of love and religion values is the first contribution in the achievement of the meaning of life of the Junior High School students in pondok pesantren AnNur II Al Murtadlo.
\end{abstract}

Keywords: meaning of life; pondok pesantren; junior high school students

\section{PENDAHULUAN}

Istilah meaning of life dikemukakan oleh Victor E. Frankl dalam konsep Logoterapi yang menekankan pada penemuan makna dalam kehidupan seseorang. Meaning of life merupakan pedoman hidup yang dianggap penting dan berharga serta memberikan nilai khusus bagi seseorang, sehingga layak dijadikan pedoman hidup (Bastaman, 2007: 45). Pencarian meaning of life merupakan motivasi utama dalam hidup. Meaning of life dapat diperoleh dimanapun dan dalam keadaan bagaimanapun juga. Bukan hanya dalam keadaan bahagia, namun juga dalam keadaan penuh tantangan (Bastaman, 2007: 46).

Ada beberapa tokoh yang mengemukakan mengenai konsep meaning of life, di antaranya yakni (1) Viktor Frankl, (2) Irvin Yalom, dan (3) Batista dan Almond. Viktor Frankl (1992: 105) menjelaskan bahwa meaning of life adalah suatu proses penemuan. Meaning of life tidak dapat diberikan oleh orang lain melaikan harus dicari sendiri. Meaning of life bersifat pribadi, khusus, unik, dan berharga. Meaning of life dapat dicapai melalui nilai kreatifitas kerja, nilai penghayatan terhadap cinta kasih dan agama, dan nilai bersikap terhadap tantangan hidup. Nilai kreatifitas kerja menginspirasi individu untuk menghasilkan, menciptakan dan mencapai melalui pekerjaan, melaksanaan tugas dan kewajiban dengan penuh tanggung jawab. Nilai penghayatan terhadap cinta kasih dan agama melalui pengalaman atas nilai-nilai kebenaran 
(melakukan sesuatu sesuai keadaan), nilai yang mendatangkan kebaikan (keselamatan, keberuntungan), nilai-nilai keindahan, nilai-nilai dan keimanan. Nilai bersikap terhadap tantangan hidup yang membawa individu untuk memilih sikap mereka terhadap kondisi negatif yang tidak dapat dihindari seperti faktor ketidakadilan dan kehilangan. Nilai bersikap terhadap tantangan hidup diwujudkan dalam menerima dengan penuh kesabaran, penuh keberanian, sikap yang diambil untuk menghadapi penderitaan (daya juang), menerima dengan ikhlas dan tabah setiap kejadian.

Meaning of life menurut Irvin Yalom (dalam Debats, 1996: 6) berdasarkan pada konsep existensialistik yang berasal dari konfrontasi individu dengan empat masalah utama, yaitu kehilangan, kebebasan, terkucilkan, dan kebermaknaan. Meaning of life dianggap sebagai respon kreatif individu. Manusia pada dasarnya memilih dan menciptakan situasi mereka sendiri. Makna tidak berasal dari luar individu, melaikan individu sendiri yang berusaha memenuhi. Meaning of life dapat dicapai melalui motif altruisme, dedikasi, kreativitas, atau memenuhi keinginan, kesenangan, dan diperlukan adanya komitmen.

Battista dan Almond (1973: 410) menemukan ada empat konsep dasar tentang meaning of life. Individu yang memiliki meaning of life akan senantiasa (a) berkomitmen terhadap meaning of life, (b) memiliki kerangka kerja atau tujuan hidup yang jelas, (c) sudah memenuhi atau dalam proses pemenuhan, dan (d) mengalami kepuasan hidup. Battista dan Almond (1973: 425) menggunakan perspektif relativistik dalam mendeskripsikan meaning of life. Hal ini berarti tidak ada sesuatu yang benar, identik antara individu satu dengan yang lain, dan adanya perbedaan dalam mencapai meaning of life. Perspektif relativistik menekankan pentingnya proses individu dalam upaya pencapaian.

Berdasarkan pendapat beberapa tokoh dapat disimpulkan bahwa meaning of life adalah suatu proses penemuan dan penilaian terhadap kehidupan yang memberikan nilai khusus, penting, dan berharga, sehingga layak dijadikan pedoman hidup sebagai acuan seseorang dalam melakukan kegiatan sehari-hari, bersifat pribadi dan unik. Meaning of life tidak dapat diberikan namun harus ditemukan sendiri dan membutuhkan adanya komitmen dalam proses penemuannya. Adapun untuk kepentingan penelitian ini lebih merujuk pada konsep meaning of life Viktor E. Frankl dalam logoterapi.

Pencapaian meaning of life dalam kehidupan siswa ialah penting. Pendidikan adalah tempat yang signifikan berpengaruh dalam pemerolehan meaning of life (Smith, 2010). Salah satu lingkungan pendidikan yang berbasis kearifan lokal khas Indonesia adalah pondok pesantren. Pondok pesantren dalam konteks penelitian ini yakni pondok pesantren An-Nur II Al Murtadlo. Kata pesantren berasal dari kata "santri" yang mendapat imbuhan awalan "pe" dan akhiran "an" yang menunjukkan tempat, maka artinya adalah tempat para santri (Ziemek, 1986 dalam Amrullah, 2011). Istilah "santri" berasal dari bahasa Tamir yang berarti guru ngaji 
(Dhofier, 2015). Pesantren diartikan sebagai tempat berlangsungnya suatu pendidikan agama Islam (Engku dan Zubaidah, 2014: 260).

Pesantren merupakan salah satu jenis pendidikan Islam Indonesia yang bersifat tradisional untuk mendalami ilmu agama Islam, dan mengamalkannya sebagai pedoman hidup dalam kehidupan sehari-hari (tafaqquh fiddin) yakni menghayati dan mengamalkan ajaran agama Islam dengan menekankan pentingnya akhlak agama Islam sebagai pedoman hidup bermasyarakat (Mastuhu, 1994: 3). Pondok pesantren An-Nur II Al Murtadlo merupakan pondok pesantren khalaf yakni pesantren yang selain mengajarkan kitab-kitab klasik juga membekali dengan pendidikan formal. Pondok pesantren secara umum memiliki panca jiwa yang diwujudkan dalam proses pembinaan karakter santri. Panca jiwa tersebut ialah (a) keihklasan, (b) kesederhanaan, (c) kemandirian, (d) ukhuwah islamiyah, dan (e) kebebasan dalam menentukan lapangan perjuangan dan kehidupan (Soebahar, 2013: 44).

Visi pondok pesantren An-Nur II Al Murtadlo yakni "Mencetak generasi sholihin sholihat yang memiliki kedalaman spiritual dan keluasan ilmu pengetahuan". Visi tersebut berdasarkan pada falsafah hidup pondok pesantren yakni menekankan pada pembentukan akhlak bagi para santri. Pembentukan akhlak sebagai pedoman pondok pesantren An-Nur II Al Murtadlo dalam memberikan pengajaran bagi santri. Sehingga pembentukan akhlak merupakan meaning of life pondok pesantren An-Nur II Al Murtadlo. Kegiatan-kegiatan di pondok pesantren An-Nur II Al Murtadlo dirancang dan dilakukan memiliki makna untuk mencapai tujuan hidup pondok pesantren. Sistem pondok yang diterapkan oleh pondok pesantren An-Nur II Al Murtadlo yakni memadukan antara ilmu agama dan ilmu umum (pengetahuan) dengan tetap mengutamakan pendidikan akhlak.

Layanan bimbingan dan konseling merupakan upaya untuk memfasilitasi perkembangan aspek psikologis, pribadi atau perilaku siswa, sehingga siswa mampu memperoleh kehidupan yang bermakna, baik bagi dirinya maupun bagi orang lain (Yusuf \& Nurihsan, 2006: 158). Pengetahuan dan pemahaman mengenai meaning of life siswa penting bagi konselor agar layanan yang dilaksanakan sesuai dengan nilai dan tujuan hidup siswa, dimana dalam penelitian ini ialah siswa SMP An-Nur yang merupakan santri di pondok pesantren An-Nur II Al Murtadlo.

Muslihati (2013: 13) menjelaskan bahwa kepribadian dibentuk oleh budaya, didasarkan bahwa siswa dalam lingkungan pondok pesantren senantiasa membawa budaya perilaku yang diajarkan oleh pondok pesantren kedalam berbagai kegiatan baik di sekolah, maupun ditempat lain tempat individu beraktivitas, budaya perilaku di pondok pesantren menempati peran yang berarti dalam membentuk identitas diri santri. Muslihati (2013: 15) menambahkan bahwa budaya juga mempengaruhi konsep diri yang merupakan inti dari eksistensialime dan secara alami akan berpengaruh terhadap pemikiran, perasaan dan perilaku individu. Jika dihubungkan dengan konsep tiga sumber nilai Frankl maka hal tersebut erat kaitannya dengan nilai kreatifitas 
kerja, nilai penghayatan terhadap cinta kasih dan agama dan nilai bersikap terhadap tantangan hidup.

Penting bagi konselor untuk mengetahui sejauh mana siswa mencapai meaning of life. Sehingga dalam pelaksanaan layanan bimbingan dan konseling yang dirancang oleh konselor dapat mengarahkan siswa mencapai meaning of life. Pencapaian meaning of life akan mengarah pada peningkatkan pencapaian kebahagiaan (happiness) bagi siswa (Gabriele, 2008 dalam Vela, 2015: 173). Melalui penelitian ini diperoleh gambaran mengenai sejauh mana siswa SMP di pondok pesantren An-Nur II Al Murtadlo mencapai meaning of life. Hasil penelitian ini diharapkan dapat memberikan gambaran mengenai pencapaian meaning of life siswa. Sehingga konselor dapat merancang layanan bimbingan dan konseling sesuai meaning of life siswa SMP di pondok pesantren An-Nur II Al Murtadlo. Tujuan penelitian ini ialah untuk mengetahui meaning of life siswa SMP di pondok pesantren An-Nur II Al Murtadlo Bululawang Malang.

\section{METODE}

Penelitian ini menggunakan rancangan penelitian kuantitatif deskriptif jenis survei. Penelitian kuantitatif deskriptif survei adalah suatu metode dalam meneliti status kelompok manusia, suatu objek, suatu set kondisi, suatu sistem pemikiran, ataupun suatu peristiwa pada masa sekarang (Nazir, 2003: 54). Penelitian ini tidak ada kontrol terhadap variabel, variabel diteliti sebagaimana adanya untuk memperoleh pemahaman mengenai capaian meaning of life siswa SMP di pondok pesantren An-Nur II Al Murtadlo. Data yang diperoleh dinyatakan dan disajikan secara kuantitatif deskriptif, berupa frekuensi dan persentase yang disajikan dalam bentuk tabel, grafik dan diagram. Adapun langkah-langkah dalam penelitian survei (Efendi, 2012: 13) yakni (1) merumuskan masalah dan tujuan penelitian, (2) menentukan konsep dan studi kepustakaan berkaitan dengan meaning of life dan pondok pesantren An-Nur II Al Murtadlo, (3) menentukan populasi dan pengambilan sampel penelitian, (4) menyusun inventori penelitian, (5) pengumpulan data, (6) mengolah data hasil penelitian, dan (7) menganalisis data dan membahas hasil penelitian.

Populasi peneliti santri pondok pesantren An-Nur II Al Murtadlo yang berada pada jenjang SMP An-Nur yaitu 2808 siswa. Pemilihan santri yang berada pada jenjang pendidikan SMP didasarkan pada asumsi bahwa siswa SMP merupakan individu yang perlu untuk mengetahui sejauh mana perilaku dalam kehidupan sehari-hari dalam upaya mencapai meaning of life sebagai pedoman dalam mencapai tujuan hidup (the purpose in life) yang diinginkan. Mengingat jumlah populasi ini besar, maka dilakukan pengambilan sampel. Pengambilan sampel menggunakan teknik random sampling. Ditentukan sampel sebesar 313 siswa.

Pengumpulan data dalam penelitian ini menggunakan inventori meaning of life siswa SMP. Jawaban setiap item inventori menggunakan skala Likert. Uji coba inventori diperoleh hasil 88 
item valid dari 124 item dengan nilai reliabilitas sebesar 0,921. Diperoleh 88 item valid dari 124 item awal. Analisis presentase bertujuan untuk mengetahui frekuensi dan presentase siswa yang tergolong dalam kategori tingkat meaning of life yang telah ditentukan.

Teknik analisis data dengan mengetahui mean, median, modus, standar deviasi dan skewness dengan program microsoft excel. Standar deviasi adalah nilai yang menujukkan tingkat variasi kelompok data atau ukuran standar penyimpangan dari nilai rata-rata (Siregar, 2010: 44). Sedangkan skewness adalah ukuran yang dapat menyatakan model distribusi dari suatu populasi (Siregar, 2010: 72). Perhitungan statistika deskriptif dilaksanakan melalui program SPSS 16.0 for windows.

\section{HASIL}

\section{Profil Pencapaian Meaning of life}

Hasil penelitian meaning of life siswa SMP di pondok pesantren An-Nur II Al Murtadlo sebesar $4 \%$ meaning of life sangat tinggi, 63\% kategori tinggi, 31\% kategori cukup, 3\% kategori rendah dan tidak ditemukan siswa dalam kategori meaning of life sangat rendah. Hasil analisis deskriptif terhadap meaning of life menujukkan nilai standar deviasi sebesar 28,49 dari nilai rata-rata. Nilai skewness $(\alpha)-0,417<0$ menujukkan bentuk kurva memiliki kemiringan negatif diartikan bahwa nilai rata-rata lebih kecil daripada nilai median dan modus (259> 256,13 < 285). Dapat disimpulkan bahwa meaning of life siswa SMP di pondok pesantren AnNur II Al Murtadlo tinggi.

\section{Profil Pencapaian Nilai Kreatifitas Kerja}

Hasil penelitian menujukkan pencapaian nilai kreatifitas kerja siswa SMP di pondok pesantren An-Nur II Al Murtadlo sebesar 1\% kategori sangat tinggi, 30\% kategori tinggi, 53\% kategori cukup, 16\% kategori rendah dan tidak ditemukan siswa dalam kategori nilai kreatifitas kerja sangat rendah. Hasil analisis deskriptif terhadap nilai kreatifitas kerja menujukkan standar deviasi sebesar 10,64 dari rata-rata. Nilai skewness $(\alpha)-0,125<0$ (mendekati 0 ) menujukkan bentuk kurva simetris diartikan bahwa nilai rata-rata sama atau mendekati sama dengan nilai median dan modus $(75>74,36>73)$. Dapat disimpulkan bahwa nilai kreatifitas kerja siswa SMP di pondok pesantren An-Nur II Al Murtadlo dalam kategori cukup.

\section{Profil Pencapaian Nilai Penghayatan terhadap Cinta Kasih dan Agama}

Hasil penelitian menujukkan pencapaian nilai penghayatan terhadap cinta kasih dan agama siswa SMP di pondok pesantren An-Nur II Al Murtadlo sebesar 32\% kategori sangat tinggi, 51\% kategori tinggi, 15\% kategori cukup, 1\% kategori rendah dan tidak ditemukan siswa dalam kategori nilai penghayatan terhadap cinta kasih dan agama sangat rendah. Hasil analisis deskriptif terhadap nilai penghayatan terhadap cinta kasih dan agama menujukkan standar deviasi sebesar 11,24 dari rata-rata. Nilai skewness $(\alpha)-0,284<0$ menujukkan bentuk kurva memiliki kemiringan negatif diartikan bahwa nilai rata-rata lebih kecil daripada nilai modus dan 
mediannya $(94>86,067<87)$. Dapat disimpulkan bahwa nilai penghayatan terhadap cinta kasih dan agama siswa di pondok pesantren dalam kategori tinggi.

\section{Profil Pencapaian Nilai Bersikap terhadap Tantangan Hidup}

Hasil penelitian menujukkan pencapaian nilai bersikap terhadap tantangan hidup siswa SMP di pondok pesantren An-Nur II Al Murtadlo sebesar 13\% kategori sangat tinggi, 58\% kategori tinggi, 26\% kategori cukup, 3\% kategori rendah dan tidak ditemukan siswa dalam kategori nilai bersikap terhadap tantangan hidup sangat rendah. Hasil analisis deskriptif terhadap nilai bersikap terhadap tantangan hidup menujukkan standar deviasi menyimpang sebesar 10,84 dari nilai rata-rata. Nilai skewness $(\alpha)-0,623<0$ menujukkan bentuk kurva memiliki kemiringan negatif diartikan bahwa nilai rata-rata lebih kecil daripada nilai modus dan mediannya $(96>95,7<97)$. Dapat disimpulkan bahwa nilai bersikap terhadap tantangan hidup siswa SMP di pondok pesantren An-Nur II Al Murtadlo dalam kategori tinggi.

Paparan hasil penelitian menujukkan bahwa meaning of life siswa SMP di pondok pesantren An-Nur II Al Murtadlo dalam klasifikasi tinggi. Secara rinci setiap nilai memiliki capaian yang berbeda-beda. Capaian tertinggi pertama yakni nilai penghayatan terhadap cinta kasih dan agama, capaian tertinggi kedua yakni nilai bersikap terhadap tantangan hidup, dan capaian ketiga yakni nilai kreatifitas kerja.

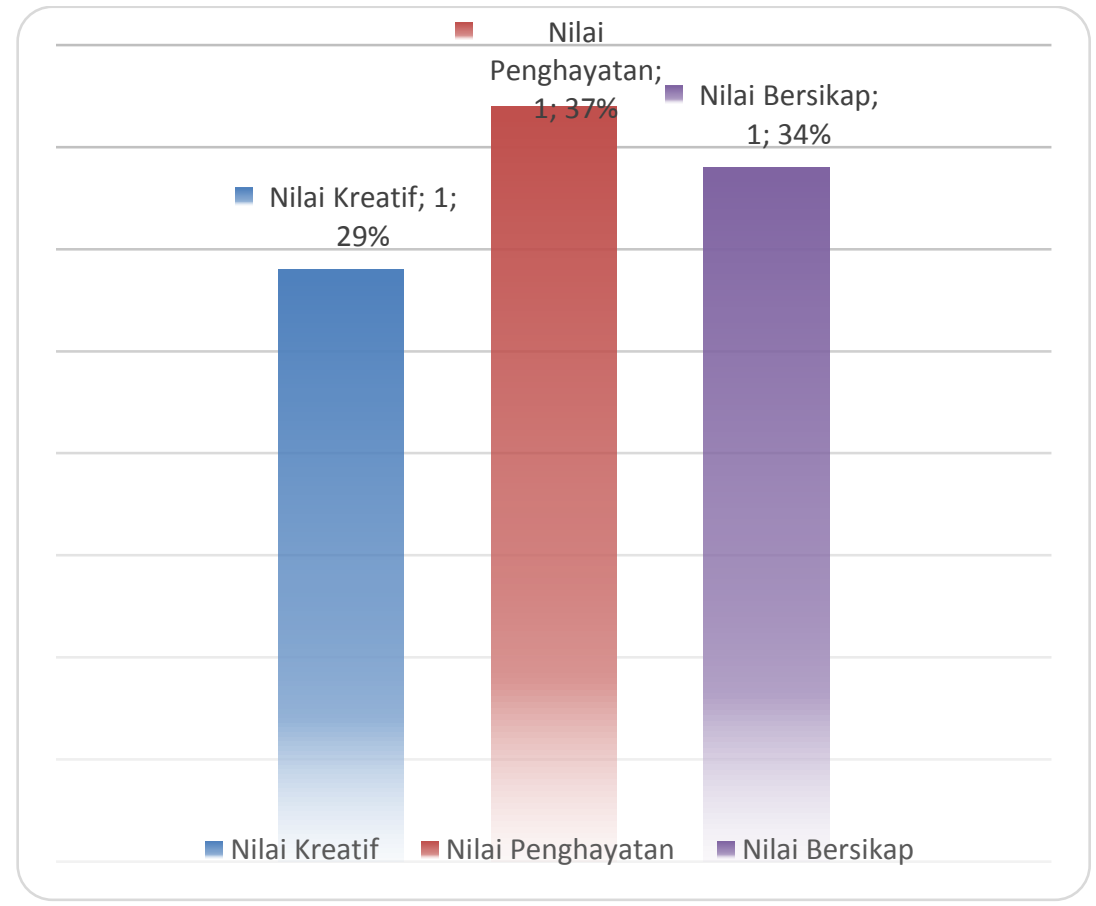

\section{Gambar 1. Pencapaian Tiga Sumber Nilai Meaning of life \\ PEMBAHASAN \\ Meaning of Life Siswa SMP di Pondok Pesantren}

Siswa yang memiliki meaning of life rendah mengarah pada kemungkinan untuk mengalami existential vacuum yakni keadaan dimana siswa merasa hidupnya tidak lagi 
bermakna, ditandai oleh rasa bosan, penuh keputusasaan dan merasa tidak memiliki tujuan hidup (Frankl, 1992: 93). Hal ini akan mempengaruhi perilaku siswa selama di sekolah, seperti sering membolos, pergi sekolah hanya sekedar menggugurkan kewajiban, sering keluar kelas, mengerjakan tugas mencontek teman dan rendahnya motivasi belajar dan pada akhirnya akan mempengaruhi penurunan prestasi belajar siswa. Meaning of life tinggi menggambarkan bahwa siswa mampu menerima keberadaan diri dengan melakukan aktivitas keterlibatan dan tanggung jawab, mampu mengambil sikap dan memilih tindakan ketika menghadapi tantangan dan hambatan.

Siswa dalam kategori meaning of life cukup harus selalu mengupayakan pencapaian menjadi lebih tinggi. Konselor dapat memberikan siswa layanan bimbingan dan konseling yang bersifat developmental untuk membantu siswa mencapai meaning of life yang lebih tinggi. Siswa dengan meaning of life tinggi akan mampu mengarahkan perilakunya untuk mencapai tujuan hidup. Siswa mampu mengarahkan perilakunya sesuai dengan apa yang menjadi cita-cita, tujuan hidup, dan merencanakan masa depan, dalam konsep meaning of life Frankl disebut dengan self-transcendence serta mampu melakukan aktualisasi diri.

\section{Nilai Kreatifitas Kerja Siswa SMP di Pondok Pesantren}

Nilai kreatifitas kerja ditujukkan dalam sikap tanggung jawab, memiliki motivasi berprestasi tinggi dengan datang sekolah tepat waktu, mengerjakan tugas sekolah dengan maksimal dan menyadari secara penuh tugas sebagai seorang siswa. Siswa juga mampu menentukan sendiri apa yang baik bagi diri dan lingkungan sehingga ia akan senantiasa mengarahkan perilakunya dalam mencapai cita-cita yang ingin diraih. Berbeda dengan siswa yang memiliki nilai kreatifitas kerja rendah, ia kurang mampu mengarahkan perilakunya sendiri dan tidak mengetahui apa yang diinginkan, dan menimbulkan perilaku siswa pergi kesekolah hanya sekedar menggugurkan kewajiban, tugas mencontek teman bahkan tidak mengerjakan, disekolah hanya belajar tanpa mengikuti kegiatan ekstrakulikuler tambahan untuk mengembangkan keterampilan hidup, motivasi berprestasi rendah, dan tidak melibatkan diri dalam perlombaan/kompetisi.

Panca jiwa pondok pesantren yang mencerminkan nilai kreatifitas kerja yakni jiwa kemandirian dan kebebasan yang bertanggung jawab. Siswa yang memiliki jiwa kemandirian akan senantiasa mampu bersikap mandiri menggunakan segala kreatifitasnya dalam bekerja dan melakukan kegiatan sehari-hari. Jiwa kemandirian juga terlihat dari proses berdirinya pondok pesantren yang tidak mengandalkan bantuan pihak lain. Jiwa kemandirian ini juga dapat diamati dari lulusan pondok pesantren yang lebih memilih berwirausaha daripada menjadi pekerja baik pemerintah maupun swasta. Jiwa kebebasan bertanggungjawab yang dimiliki oleh siswa akan senantiasai menuntun pada pengambilan tindakan yang bertanggungjawab sesuai dengan nilai- 
nilai ajaran di pondok pesantren, sehingga setiap perbuatan yang dilakukan dilandasi dengan kesadaran bahwa perilakunya akan dimintai dipertangungjawabkan kepada Allah SWT.

\section{Nilai Penghayatan terhadap Cinta Kasih dan Agama Siswa SMP di Pondok Pesantren}

Nilai penghayatan terhadap cinta kasih dan agama dalam pondok pesantren An-Nur II Al Murtadlo diwujudkan dalam nilai-nilai yang diyakini dan dianggap penting untuk diajarkan kepada siswa sebagai pendidikan akhlak. Nilai penghayatan terhadap cinta kasih dan agama diantaranya yakni saling menghormati dengan semua orang, patuh terhadap semua peraturan baik yang diterapkan, jujur baik perkataan maupun perbuatan, siswa diajarkan pentingnya membangun kerja sama dan tolong menolong melalui pengalaman hidup dalam kegiatan seharihari. Siswa juga dibiasakan menjaga kebersihan diri dan lingkungan sekolah bersih, siswa dibiasakan untuk berdo'a bersama sebelum dan setelah pelajaran belangsung. Nilai penghayatan terhadap cinta kasih dan agama dalam keimanan salah satunya diaplikasikan dengan pembacaan amalan-amalan yang diterapkan di pondok pesantren seperti yasin, burdah dan surat al-waqi'ah yang memiliki faedah tersendiri bagi keyakinan pondok pesantren.

Siswa yang memiliki nilai penghayatan terhadap cinta kasih dan agama tinggi mampu menghayati setiap pengalaman kehidupan sebagai seorang pelajar sebagai proses pencapaian meaning of life. Siswa menunjukkan perilaku saling menghormati, memiliki cinta kasih dengan sesama, mampu menyesuaikan diri dengan lingkungan dan menganggap aktivitas di sekolah setiap hari adalah hal yang menyenangkan. Namun siswa yang memiliki nilai penghayatan rendah menganggap kegiatan sehari-hari membosankan dan menjenuhkan. Keadaan ini disebut sebagai neorosis noogenic (Frankl, 1992: 111). Neorosis noogenic, merupakan suatu kondisi yang dapat menghambat penyesuaian diri bahkan prestasi, sehingga memunculkan kondisi kebosanan dan jenuh dengan kegiatan sehari-hari serta kehilangan minat untuk melakukan aktivitas (Bastaman, 2007: 81).

Panca jiwa pondok pesantren yang mencerminkan nilai penghayatan terhadap cinta kasih dan agama yakni jiwa keikhlasan dan jiwa ukhuwah Islamiyah. Jiwa keikhlasan tercermin dalam sifat melakukan segala aktifitas atas dasar ibadah tidak untuk memperoleh keinginan apapun. Jiwa ini tampak pada warga pondok pesantren, mulai dari kiai, ustadz, hingga para santri. Kiai dengan tulus ikhlas memberikan pengajaran kepada santri, demikian dengan ustadz yang senantiasa mengabdi bagi kiai. Terlebih bagi santri, budaya sendhiko dawuh kepada kiai sangat lekat bagi siswa di pondok pesantren. Apapun ajaran, penyampaian, dan permintaan kiai akan senantiasa dilakukan tanpa membantah sehingga memunculkan lahirnya budaya restu kiai terus bertahan hingga sekarang.

Budaya sendhiko dawuh menujukkan adanya high power distance antara kiai dengan santri. Kiai diperlakukan dengan sangat hormat, sehingga warga pondok pesantren sangat patuh. Kiai 
sebagai guru yang memegang pusat pembelajaran di pondok pesantren. Kiai memberikan pengajaran dan setiap apa yang disampaikan dan diminta kiai harus ditaati oleh santri. Kualitas diri santri ditentukan oleh kapasitas dan nama besar seorang kiai (Hofstede, 2010: 69).

Cinta kasih seorang kiai kepada santri diwujudkan dalam ajaran, tuntunan dan menjadi panutan dalam kebaikan yang mengarah pada iman, islam dan ihsan. Bagi santri cinta kasih kepada kiai diwujudkan dengan senantiasa patuh, tidak membangkang apalagi melawan. Jiwa keikhlasan sesama santri diwujudkan dengan saling tolong menolong, saling membantu apapun kegiatan di pondok pesantren.

Cinta kasih santri terhadap diri sendiri dilakukan dengan melakukan amalan-amalan seperti pembacaan al-waqi'ah, yasin, dan burdah, agar senantiasa dalam pertolongan Allah SWT. Cinta kasih dengan sesama santri diantaranya yakni dengan saling tolong menolong dengan tulus ikhlas, budaya saling berbagi dan saling meminjam menjadi hal yang lumrah dalam kehidupan pesantren. Cinta kasih dengan sesama santri tercermin dalam jiwa ukhuwah islamiyah. Jiwa ukhuwah islamiyah diwujudkan dengan tidak membeda-bedakan teman, semua siswa hidup rukun.

\section{Nilai Bersikap terhadap Tantangan Hidup Siswa SMP di Pondok Pesantren}

Siswa yang memiliki nilai bersikap terhadap tantangan hidup tinggi terlihat dari kesungguhan dan tanggungjawab dalam kegiatan sehari-hari dalam mengaplikasikan panca jiwa pondok pesantren, siswa mampu mengambil sikap atas tantangan hidup yang dihadapi. Sehingga tantangan hidup dilihat sebagai hikmah bukan musibah yang pada akhirnya menuntun siswa untuk menemukan meaning of life.

Nilai bersikap terhadap tantangan dalam kehidupan pondok pesantren diaplikasikan dalam jiwa kesederhanaan pondok pesantren. Jiwa kesederhanaan dalam diri siswa terlihat dari kesabaran dalam menghadapi berbagai situasi dan kondisi di pondok pesantren, menerima dengan tabah dan ikhlas ketika apa yang diperoleh tidak sesuai dengan yang diharapkan, menerima apa adanya kehidupan di pondok namun tetap memiliki motivasi untuk melanjutkan pendidikan baik di pondok pesantren maupun di sekolah. Jiwa kesederhanaan ini juga mengandung unsur adanya kekuatan hati, ketabahan, dan pengendalian diri dalam menghadapi berbagai macam tantangan hidup sehingga memunculkan jiwa yang besar, berani, bergerak maju, dan pantang menyerah dalam menghadapi tantangan hidup.

Berbeda dengan siswa dengan nilai bersikap terhadap tantangan hidup rendah perilakunya cenderung mengarah pada perilaku konformisme dan totaliterisme (Frankl, 1992: 111). Perilaku konformisme yakni melakukan segala sesuatu seperti apa yang orang lain lakukan (tidak memiliki tujuan hidup sendiri), sedangkan perilaku totaliterisme yakni melakukan apa yang orang lain/lingkungan berharap ia lakukan (semata hanya mengikuti apa yang diinginkan orang lain terhadapnya dirinya). 
Implikasi Meaning of life Siswa SMP di Pondok Pesantren Bagi Layanan Bimbingan dan

\section{Konseling}

Paparan hasil penelitian menujukkan bahwa meaning of life siswa SMP di pondok pesantren An-Nur II Al Murtadlo dalam klasifikasi tinggi. Meaning of life dalam pencapaiannya memiliki tiga sumber nilai. Secara rinci setiap nilai memiliki capaian yang berbeda-beda. Capaian tertinggi pertama yakni nilai penghayatan terhadap cinta kasih dan agama, capaian tertinggi kedua yakni nilai bersikap terhadap tantangan hidup, dan capaian ketiga yakni nilai kreatifitas kerja. Merujuk pada falsafah hidup pondok pesantren bawasannya fokus utama pondok pesantren adalah memperbaiki akhlak siswa, mencetak generasi yang sholihin dan sholihat.

Visi misi pondok pesantren yakni mencetak santri sholihin dan sholihat. Santri sholihin dan sholihat adalah siswa yang memiliki kepribadian yang baik dalam semua dimensi yang termanifestasikan dalam seluruh kegiatan hingga infrastruktur bangunan yang indah, rapi, bersih yang mendukung perilaku santri sholihin dan sholihat (Amrullah, 2011: 173). Fokus utama pondok pesantren An-Nur II Al Murtadlo adalah terbentuknya karakter yang akhlaqul karimah, mandiri, rendah hati, istiqomah dan kerja keras (Amrullah, 2011: 201).

Menurut Mastuhu (1994: 56) pesantren adalah lembaga pendidikan untuk mempelajari, memahami, mendalami, menghayati, dan mengamalkan ajaran Islam dengan menekankan pentingnya moral keagamaan sebagai pedoman perilaku sehari-hari yang bertujuan menciptakan mengembangkan kepribadian muslim, beriman dan bertaqwa kepada Tuhan, berakhlak mulia, bermanfaat bagi masyarakat, dan mandiri. Pesantren sangat menekankan pentingnya akhlak ditengah-tengah kehidupan bermasyarakat.

Pembentukan akhlak dalam konsep meaning of life Logoterapi, terdapat dalam nilai-nilai penghayatan terhadap cinta kasih dan agama (experiential values). Pembentukan akhlak dalam pondok pesantren umumnya diberikan kepada siswa melalui kegiatan-kegiatan sehari selama siswa menjadi santri di pondok pesantren. Sehingga nilai-nilai akhlak yang diajarkan benarbenar dihayati oleh siswa. Hal inilah yang membuat pondok pesantren sangat erat dengan budaya warganya memiliki akhlakul karimah.

Tingkah laku individu sebagai produk budaya dimana hal ini dipengaruhi oleh nilai-nilai yang dianutnya dan berpengaruh pada perilaku sehari-hari (Rofiq, 2016: 10). Nilai budaya yang tampak pada tingkah laku individu menujukkan keunikan dan kekhasan. Dalam budaya pondok pesantren, setiap nilai yang diajarkan kepada santri merupakan falsafah pendiri pondok pesantren, dalam pondok pesantren An-Nur II Al Murtadlo ialah pembentukan akhlak (mencetak santri sholihin dan sholihat). Nilai-nilai yang dianut dalam pondok pesantren dijadikan pedoman hidup santri dalam bertingkah laku. 
Siswa akan lebih menerima layanan bimbingan dan konseling ketika sesuai dengan pedoman hidupnya (meaning of life), terutama nilai penghayatan terhadap cinta kasih dan agama sebagai konstributor capain tertinggi meaning of life yakni terkait pembentukan akhlak. Perdesen (Gusria, 2015: 24) menyatakan, tanpa pemahaman terhadap nilai-nilai budaya yang dimiliki siswa, layanan bimbingan dan konseling tidak dapat berjalan optimal. Hal ini dapat dimaknai bahwa proses layanan yang diberikan oleh konselor tidak bisa mengabaikan aspek budaya.

Salah satu kompetensi yang harus dimiliki konselor yakni kompetensi multibudaya. Kompetensi multibudaya ialah adanya kepekaan budaya, mampu melepaskan bias-bias budaya, memahami perbedaan budaya, dapat mengapresiasi perbedaan budaya dan memiliki keterampilan yang responsif secara kultural (Rofiq, 2016: 41). Kompetensi multibudaya ialah dengan mengedepankan penghargaan dan penghormatan keunikan terhadap konseli untuk mencapai kemandirian dan optimalisasi perkembangan (Muslihati, 2013: 29).

Konselor yang memiliki dan mengembangkan kompetensi multibudaya akan lebih efektif ketika menghadapi konseli dengan perbedaan budaya (Hill, 2013: 262). Siswa akan merasa percaya dan nyaman ketika konselor menujukkan empati budaya, bersikap menghargai kekhasan pola pikir, dan perilakunya (Muslihati, 2013: 31). Individu merupakan bagian atau produk dari budaya mereka tinggal, sehingga perilaku mereka tidak dapat dipahami tanpa memahami budayanya (Hatunoglu, 2017: 8).

Kompetensi multibudaya ditunjukkan dan diaplikasikan oleh konselor ketika berada di tempat yang berbeda budaya dengan dirinya. Layanan bimbingan dan konseling yang multibudaya dapat terwujud apabila dalam prosesnya konselor menujukkan empati dan ketulusan dalam memperhatikan dan menghargai kekhasan aspek-aspek multibudaya pada konseli (perspektif emik) dengan tetap memperhatikan dimensi universal pelaksanaan konseling (perspektif etik) (Muslihati, 2013: 20).

Standar kompetensi konselor (Permendiknas, 2008: 3) diantaranya yaitu memahami secara mendalam konseli yang hendak dilayani, menguasai landasan teoritis bimbingan dan konseling, menyelenggarakan bimbingan dan konseling yang memandirikan, dan mengembangkan pribadi dan profesional secara berkelanjutan. Secara rinci standar kompetensi konselor terbagi dalam empat kompetensi yakni kompetensi pedagogik, kompetensi kepribadian, kompetensi sosial, dan kompetensi profesional. Jika dikaitkan dengan perspektif emik dan etik, maka perspektif emik erat kaitannya dengan kompetensi kepribadian konselor, sedangkan perspektif etik berkaitan erat dengan kompetensi profesional konselor dengan menjalankan tugas secara profesional yang berlaku secara universal sesuai dengan dasar dan landasan kelimuan.

Kompetensi kepribadian konselor tercermin dalam menghargai, memperlakukan dan memandang siswa secara utuh dan menyeluruh termasuk mempertimbangkan meaning of life, 
nilai-nilai dan segala aspek kehidupan yang terkait dengan individu. Rogers (Corey, 2009: 169). mengemukakan ada tiga sikap dasar konselor agar dapat menciptakan kondisi yang mampu mendorong siswa untuk maju dan memaksimalkan potensi yang dimiliki, yakni genuine, unconditional positive regards, dan empati. Seorang helper diharapkan memiliki keterampilan membina hubungan yang baik dengan individu, respect, memahami nilai budaya, empati dan percaya bahwa individu mampu bertanggungjawab atas dirinya sendiri (Egan, 2010: 36). Konselor diharapkan mampu mengembangkan sikap dan keterampilan tersebut guna meningkatkan kompetensi kepribadian sebagai konselor profesional yang multibudaya. Layanan bimbingan dan konseling akan lebih mudah diterima siswa ketika mempertimbangkan unsur nilai penghayatan terhadap cinta kasih dan agama yang sesuai dengan nilai-nilai pondok pesantren (selaras dengan ajaran yang diperoleh di pondok pesantren) yakni akhlaqul karimah, mandiri, rendah hati, istiqomah dan kerja keras.

Nilai penghayatan terhadap cinta kasih dan agama menjadi pertimbangan pertama bagi konselor ketika memberikan layanan bimbingan dan konseling. Berbagai bidang bimbingan dan konseling tidak bisa lepas dari nilai penghayatan terhadap cinta kasih dan agama sebagai unsur utama pencapaian meaning of life, meskipun nilai penghayatan terhadap cinta kasih dan agama lebih erat kaitannya dengan bidang pribadi dan bidang sosial, namun layanan dalam bidang belajar dan karier juga mempertimbangkan aspek nilai penghayatan terhadap cinta kasih dan agama. Sehingga layanan bimbingan dan konseling bagi siswa di pondok pesantren akan berbeda dengan sekolah pada budaya berbeda. Sebagai contoh layanan bimbingan belajar sekolah di pondok pesantren akan lebih memfokuskan pada apa makna belajar dan hakikat belajar sebagai salah satu bentuk ibadah daripada melatihkan berfikir kritis bagi siswa. Layanan dalam bidang karier lebih mengutamakan bagaimana memandang hakikat sebuah pekerjaan. Layanan bimbingan dan konseling yang dilakukan oleh konselor benar-benar dapat memfasilitasi serta memandirikan siswa mencapai tugas perkembangan yang utuh dan optimal sesuai dengan falsafah hidup pondok pesantren. Siswa akan lebih mudah menerima dan layanan bimbingan akan lebih berhasil.

Terkait proses konseling demikian, konselor diharapkan selalu mempertimbangkan nilainilai dalam aspek nilai penghayatan terhadap cinta kasih dan agama siswa. Konseling akan lebih baik jika intervensi yang diberikan sesuai aspek nilai penghayatan terhadap cinta kasih dan agama siswa. Konselor dengan kompetensi multibudaya lebih profesional ketika melakukan konseling dengan berbagai latar belakang budaya serta dapat mengurangi resiko kesalahpahaman dengan konseli selama proses konseling yang seringkali menyebabkan kegagalan selama proses konseling (Garsia, 2013: 2). Konselor juga diharapkan mampu memahami adanya high power distance anatara kiai dengan santri. Siswa cenderung lebih sulit terbuka dan mengikuti proses konseling ketika behadapan dengan permasalahan yang 
menyangkut hubungan dengan kiai. Intervensi yang diberikan tanpa mempertimbangkan emosional terkait hal tersebut bukan akan membantu siswa justru mungkin akan menimbulkan masalah baru (MacCluskie, 2010: 134)

\section{SIMPULAN}

Meaning of life siswa SMP di pondok pesantren An-Nur II Al Murtadlo memiliki kategori tinggi, menujukkan bahwa dalam melakukan kegiatan sehari-hari sudah mengarah pada pemenuhan meaning of life. Setiap sumber nilai memiliki capaian yang berbeda. Capaian pertama yakni banyak siswa SMP mencapai nilai penghayatan terhadap cinta kasih dan agama dalam kategori tinggi, kemudian banyak siswa SMP mencapai nilai bersikap terhadap tantangan hidup dalam kategori tinggi, dan yang terakhir yakni rata-rata siswa SMP mencapai nilai kreatifitas kerja cukup. Menujukkan bahwa nilai penghayatan terhadap cinta kasih dan agama sebagai konstribusi tertinggi dalam pencapaian meaning of life bagi siswa SMP di pondok pesantren An-Nur II Al Murtadlo. Sehingga dapat dikatakan sesuai dengan falsafah hidup pondok pesantren yakni pembentukan akhlak yang mengandung unsur kebenaran (melakukan sesuatu sesuai keadaan), kebaikan (keselamatan, keberuntungan), keindahan, keimanan, dan cinta kasih. Berdasarkan temuan ini diharapkan layanan bimbingan dan konseling yang dirancang oleh konselor SMP di pondok pesantren An-Nur II Al Murtadlo mempertimbangkan meaning of life terutama nilai penghayatan terhadap cinta kasih dan agama sebagai nilai yang paling dominan dalam pencapaian meaning of life siswa SMP di pondok pesantren An-Nur II Al Murtadlo.

\section{DAFTAR PUSTAKA}

Amrullah, A. M. K. (2011). Perubahan Model Penyelenggaraan Pendidikan Pesantren. Disertasi tidak diterbitkan, Malang: Pascasarjana Universitas Negeri Malang

Bastaman, H. D. (2007). Logoterapi. Psikologi untuk Menemukan Makna Hidup dan Meraih Hidup Bermakna. Jakarta: Raja Grafindo Persada

Battista, J. \& Almond, R. (1973). The development of meaning in life. Psychiatry: Interpersonal and Biological Processes, 36(4), 409-427. Dari http://dx.doi.org/10.1521/00332747. 1973.11023774

Corey, G. (2009). Theory and Practice of Counseling and Psychotherapy. USA: Thomson Brooks/Cole

Debats, D. L. (1996). Meaning in Life: Psychometric, Clinical and Phenomenological Aspects. Rijksuniversiteit Groningen. (1-155). Netherland: Thesis University Groningen. Dari http://www.rug.nl/research/portal/files/10223334/thesis.pdf

Dhofier, Z. (1994). Tradisi Pesantren. Studi tentang Pandangan Hidup Kyai. Jakarta: LP3ES

Dhofier, Z. (2015). Tradisi Pesantren Studi tentang Pandangan Hidup Kyai dan VisinyaMengenai Masa Depan Indonesia. Jakarta: LP3ES

Efendi, Sofian \& Tukiran. (2012). Metode Penelitian Survey. Jakarta: LP3ES

Egan, G. (2010). The Skilled Helper. USA: Brooks/Cole, Cengage Learning 
Engku, I. \& Zubaidah, S. (2014). Sejarah Pendidikan Islam. Bandung: Remaja Rosdakarya

Frankl, V. (1992). Man's Search for Meaning. Boston: Beacon Press

Garcia, J., etc., (2013). Enhancing Multicultural Empathy in the Classroom and Beyond: A Proposed Model for Training Beginner Counselors. Paper based on a program National Association of Multicultural Concerns, presented at the 22-25 July 2009, in Memphis, TN (Online), (http://www.Counseling.org/library)

Gusria. (2015). Karakter Individu Mandiri dalam Karya Buya Hamka dan Konstribusinya bagi Bimbingan Berbasis Budaya. Tesis Tidak diterbitkan: UM

Hatunoglu, A. (2017). Turkish School Counselors and Counselor Educators' Perceptions about Multicultural Counseling. International Journal for the Advancement of Counselling, 39, 1-13. DOI: $10.1007 / \mathrm{s} 10447-016-9278-3$

Hill. N. R.,etc. (2013). Multicultural Awareness, Knowledge, and Skills Among American Counselor Trainees: Group Differences in Self-Perceived Competence Based on Dispositional and Programmatic Variables. International Journal for the Advancement of Counselling, 35, 261-272. DOI: 10.1007/s10447-012-9181-5

Hofstede, G. (2010). Cultures and Organizations: Software of The Mind Intercultural Cooperation and Its Importance for Survival. United States: McGraw-Hill

Mastuhu. (1994). Dinamika Sistem Pondok Pesantren: Suatu Kajian tentang Unsur dan Nilai Sistem Pendidikan Pesantren. Jakarta: INIS

MacCluskie, K. (2010). Aquiring Counseling Skills: Integrating Theory, Multiculturalism, and Self-Awareness. New Jersey: Pearson Education Inc.

Muslihati. (2013). Konseling Multibudaya dan Kompetensi Multibudaya Konselor. Malang: Kementrian Pendidikan dan Kebudayaan Universitas Negeri Malang Fakultas Ilmu Pendidikan

Permendiknas. (2008). Standar Kualifikasi Akademik Dan Kompetensi Konselor. Jakarta

Rofiq, A. A. (2016). Nilai-Nilai Budaya Suku Using Banyuwangi dalam Kitab Lontar Yusuf dan Aplikasinya pada Konseling. Disertasi tidak diterbitkan, Malang: Pascasarjana Universitas Negeri Malang

Smith, P. (2013). Psychosocial Learning Environments and the Mediating Effect of Personal Meaning upon Satisfaction with Education. Learning Environments and Personal Meaning, 16, 259-280. DOI: 10.1007/s10984-013-9135-9

Siregar, S. (2010). Statistika Deskriptif untuk Penelitian. Jakarta: Raja Grafindo Persada

Soebahar, A. H. (2013). Modernisasi Pesantren. Yogyakarta: LKIS Printing Cemerlang

Yusuf, S. \& Nurihsan J. (2008). Landasan Bimbingan dan Konseling. Bandung: Remaja Rosdakarya 